\title{
Anti-FGFR2 Antibody BAY1179470
}

National Cancer Institute

\section{Source}

National Cancer Institute. Anti-FGFR2 Antibody BAY1179470. NCI Thesaurus. Code C107683.

An antibody ag ainst the fibroblast growth factor receptor type 2 (FGFR2), with potential antineoplastic activity. Upon administration, the anti-FGFR2 antibody BAY1179470 binds to and inhibits FGFR2, which may result in the inhibition of both FGFR2 phosphorylation and FGFR2-mediated signal transduction pathways. This results in the inhibition of cell proliferation and the induction of cell death of FGFR2-expressing tumor cells. FGFR2, upregulated in many tumor cell types, is a receptor tyrosine kinase, which is essential to tumor cellular proliferation, differentiation and survival. 